Article

\title{
The Factors that Affect Usage Intentions and Travel Intentions of Travel-Related WeChat Official Accounts
}

\author{
Yanyan Wang ${ }^{1,2}$, Yann-Jou Lin ${ }^{1}$ and Bau-Show Lin ${ }^{1, *}$ \\ 1 Department of Horticulture and Landscape Architecture, National Taiwan University, Taipei 10673, Taiwan; \\ d00628011@ntu.edu.tw (Y.W.); yannjlin@ntu.edu.tw (Y.-J.L.) \\ 2 Strait College, Minjiang University, Fuzhou 350108, China \\ * Correspondence: doralin@ntu.edu.tw; Tel.: +88-62-3366-4867
}

Received: 23 June 2020; Accepted: 22 July 2020; Published: 29 July 2020

check for updates

\begin{abstract}
WeChat Official Accounts (WOAs) - a feature of WeChat-are thriving. However, studies on travel-related WOAs remain scarce and lack depth. This study aimed to identify the factors that influence usage intentions and travel intentions in regard to travel-related WOAs. Based on the Uses and Gratifications (U\&G) theory, this study developed a theoretical model and examined the model through a web-based questionnaire. The questionnaire was distributed through the online survey tool Sojump. After analyzing the obtained data via structural equation modeling, the results revealed that: (1) social, entertainment, and information motivations are the primary factors influencing usage intentions; (2) information and entertainment motivations are important factors influencing travel intentions; and (3) usage intentions positively affect travel intentions and play a mediating role. The findings carry theoretical and practical significance regarding how travel-related WOAs can improve users' usage and travel intentions, as well as value for the actual management and marketing of WOAs.
\end{abstract}

Keywords: motivation; usage intention; travel intention; structural equation modelling

\section{Introduction}

Since it was first launched by Tencent in January 2011, WeChat has accumulated over one billion active users and has developed into one of the most widely used smartphone applications [1]. The WeChat Official Accounts (WOAs) were established on 23 August 2012, as a platform designed primarily to allow enterprises, media companies, government departments, and individuals to share, communicate, and access information through features such as push publishing, information queries, online interactions [2]. According to the WeChat 2018 Influence Report and WeChat Economic Data Report, the number of WeChat Official Accounts (WOAs) exceeded 10 million by the end of 2017, among which active accounts reached 3.5 million, making WOAs important platforms for public discourse and important channels for the dissemination [3]. As of 2020, the number of WeChat official accounts had risen to 20 million [4].

With the upgrading of tourism infrastructure, people travel more frequently. China's tourism industry has expanded enormously and developed an extensive market base, becoming the foremost market and the largest innovation testbed in global tourism [5]. In 2019, people traveling within China reached 6.01 billion and tourism revenue amounted to about 5.73 trillion yuan (amount to approximately 0.81 trillion dollars), for annual growth rates of $8.4 \%$ and $11.7 \%$ respectively [6]. An increasing number of tourist destinations are establishing their own WOAs in attempts to enhance promotion; expand the coverage, forms, and scope of their services; and consolidate brand image [7]. From a sustainability perspective, mobile technology in general is expected to contribute to the development of sustainable tourism [8]. Information and Communication Technologies (ICT) and applications (apps) for tourists 
are also essential tools in destination promotion and marketing [9]. In fact, WOAs also have developed into a common means of marketing, and enterprises are taking active steps to market their products through WOAs [10].

In contrast to the research on the blooming of China's tourism industry, however, studies on travel-related WOAs are scarce, and the few that exist lack depth [11]. At present, research on WOAs has largely focused on the application of real-time mobile communication tools in areas such as medical fields, education, and the academic domain [12-14]. Despite WeChat's gigantic user base, growth in the number of WOA users is sluggish [15]. Users' lack of concern and understanding regarding WOAs has limited the functionality and roles of the mobile terminal as a service and marketing platform [16]. Hence, maintaining or expanding the user base by increasing and sustaining usage intentions has become a salient issue that urgently requires a solution. Bhattacherjee reported that attracting users' initial adoption and usage of technology is merely the first step for achieving the successful implementation of an information system, and that customer retention is the key to retaining such success [17]. Thus, exploration of the usage and travel intentions associated with travel-related WOAs is of immense significance for tourism businesses.

Considering the issues identified above, this study adopted uses and gratifications $(U \& G)$ theory as its theoretical framework, to identify the motives and gratifications associated with intentions to use travel-related WOAs and intentions to travel. The data were collected by the online survey tool Sojump. After analyzing the obtained data via structural equation modeling, the findings carry theoretical and practical significance regarding, as well as value for the actual management and marketing of WOAs. This study results contribute to the knowledge gap regarding mobile social media technology guided by U\&G in travel-related WOAs context.

\section{Theoretical Background}

The U\&G theory, originated from the functionalist perspective on mass media communication, was first developed in research on the effectiveness of the radio medium in the 1940s [18]. It provides a conceptual framework for examining whether users are willing to adopt and accept new media [19]. According to the $U \& G$, people are active in choosing and using particular media as required. Their need-oriented motives influence their use of communication media, resulting in affective, cognitive and behavior outcomes [20].

The U\&G theory has been frequently applied to computer-mediated communication (CMC) research [21]. A review of the literature reveals that the previous social media studies mainly focused on using U\&G regarding adopting Facebook, Weibo, WeChat or other social networking sites (SNS) [22-25].

The U\&G has also been used to study online tourism-related behavior [26,27]. Considerable literature also explored peoples' online consumption behavior, tourism willingness, and TV shopping behavior from the perspective of the $U \& G$ theory. Huang uses the $U \& G$ theory to discuss the online consumption behaviors of Taiwanese consumers [28]; Luo uses the U\&G theory to explore the effects of information, entertainment and stimulus on a variety of online consumption behaviors [29]; A study by Pennington et al. uses the $U \& G$ theory to observe the relation between tourists' feature, general Internet search, and tourist willingness [26]. Another study, by Mendes-Filhoa et al. uses the U\&G theory to study how tourists can use online travel reviews (OTRs) on mobile devices to make tourist plans [27]. In summary, the U\&G theory has been applied to identify users' behavior in different contexts.

Considering the issues identified above, this study adopted the $U \& G$ theory, to identify the motives associated with intentions to use travel-related WOAs and intentions to travel, thus constructing the theoretical model of this study. 


\section{Hypotheses and Theoretical Model}

\subsection{Motivations and Usage Intentions}

Motivation can be defined as a general tendency that drives the behaviors people perform to satisfy their needs or desires [30]. Motivation is also one of the factors that influences peoples' selective choice and subjective interpretation of media information [31]. Meanwhile, usage intentions are clients' likelihood of using a specific product or service [32].

Jung et al. identified six main reasons for the use of Cyworld (a social network service) in Korea: entertainment, self-expression, professional advancement, passing time, communication with family and friends, and knowing the trends [33]. Meanwhile, Wei identified five motives regarding the usage of mobile phones: passing time, social interaction, feeling an increased sense of security, instrumentality, and communication facilitation [34]. Raacke and Bonds-Raacke discovered that the major motives for using Facebook and MySpace were to seek "friends" and "information" [35]. Similarly, Brandtzæg and Heim listed the following four major motives for using the four most popular social networking services in Norway (namely, Underskog, Nettby, HamarUngdom, and Biip): information, entertainment, social interaction, and expressing personal identity; among these motives, social interaction was considered to be foremost [36].

Analysis of more recent studies yielded the following results: Li et al. found that utilitarian gratification (achievement), social motivation (social presence and interaction), and hedonic motivation (fantasy, escapism, and enjoyment) can be obtained from games played on social networks [37]; Liu et al. revealed that content motivation (information sharing, self-documentation, and self-expression) and technology motivation (convenience, media appeal, and social presence) are derived from the use of microblogging [38]; Zhang et al. found that, among the four types of value (social value, information value, emotional value, and hedonic value) perceived by WeChat users in the service, social value and hedonic value are the only ones that affect their continuance intentions [39]; Hwang and Cho discovered that social value and entertainment value positively affect intention to use Instagram [40].

Analysis of the above usage motivations and gratifications showed that functional motivations (instrumentality and information-seeking), leisure and entertainment motivations (pleasure and passing time), and social motivations (interpersonal communication) are common among previous study findings. In other words, they have been proven to be the primary motivations behind the use of new technology, and suffice to satisfy humans' basic needs. Meanwhile, an important feature of travel-related WOAs is the provision of convenient products or services that can save users time and effort, including making enquiries regarding plane tickets, hotel reservations, and other tickets, and membership offers [41,42]. Users' self-service motivation reflects the desire to reduce time cost, effort, and psychological cost through certain methods, objects, or services. Hence, this study hypothesizes:

Hypothesis 1 (H1). Information motivation positively affects usage intentions regarding travel-related WOAs.

Hypothesis 2 (H2). Self-service motivation positively affects usage intentions regarding travel-related WOAs.

Hypothesis 3 (H3). Entertainment motivation positively affects usage intentions regarding travel-related WOAs.

Hypothesis 4 (H4). Sociability motivation positively affects usage intentions regarding travel-related WOAs.

\subsection{Motivations and Travel Intentions}

Motivation theory declared that motivations are the direct influencing factors of users' behavioral intention [43], Motivations are the physical and psychological needs and desires that drive the whole and directly influence individual behavior and actions [44]. Dann mentioned in tourism research that the concept of motivation can be divided into push and pull: intrinsic motivation is the push factor, 
which is invisible; extrinsic motivation is the pull factor, mainly the characteristics and attraction of the destination. The causality of motivation for behavior is confirmed [45-47], and recent studies also show that travel motivation has a positive impact on travel intentions, which themselves lead to travel behavior [48-51].

Travel intentions, an important concept in the study of tourism, are the psychological process through which travelers select their destinations during travel-related decision-making. In their attempt to predict travelers' behaviors, Woodside and Lysonski examined situational factors and consequently opined that travel intentions reflect travelers' strong desire to visit a certain location at a certain time [52].

Previous research has found that entertainment motivation provides psychological benefits of travel which, in turn, influences travel intentions. A study by Mannell and Iso-Ahola posited that the psychological benefits produced by leisure and tourist experiences originate from the interplay between two motivational forces: the urge to escape from routine and stressful environments and the urge to seek recreational opportunities [53]. Studies have also found that information and social motivation affect traveler satisfaction which, in turn, influences travel intentions. For instance, Ross and Iso-Ahola identified a considerable similarity between the dimensions of motivation and traveler satisfaction, and suggested that knowledge-seeking, social interaction, and escapism are important shared motivation and satisfaction factors [54]. The senior tourism market has received increased attention. Using Taiwanese seniors as the study sample, the authors identified that novelty-seeking not only can be stimulated by affect, but also aroused travel intention [55]. The effects of social motivations, entertainment motivations, and information-seeking on travel intentions have also been highlighted in more recent studies [56,57]. For example, Martin et al. (2019) found that utilitarian/hedonic motivations of consumers influenced brand interaction and behavioral intention of consumers.

Considering the above and the feature of travel-related WOAs, information-seeking, self-service, entertainment, and social motivations may be the primary motivations behind travel intentions. Therefore, we propose the following hypotheses:

Hypothesis 5 (H5). Information motivation positively affects travel intentions regarding travel-related WOAs.

Hypothesis 6 (H6). Self-service motivation positively affects travel intentions regarding travel-related WOAs.

Hypothesis 7 (H7). Entertainment motivation positively affects travel intentions regarding travel-related WOAs.

Hypothesis $\mathbf{8}$ (H8). Sociability motivation positively affects travel intentions regarding travel-related WOAs.

\subsection{Usage Intentions and Travel Intentions}

Previous studies have shown that attitude and behavioral intentions are positively correlated [58-61]. Verhagen et al. clearly show that utilitarian, social, and hedonic motivations have a significant impact on customer behavioral intention [62]. Moreover, Charfi and Cui et al. show the mediating effects of usage intentions between utilitarian and hedonic motivations and travel intentions $[63,64]$. A study by Leung and Bai found that travelers' active engagement with hotel social media pages influences their revisit intentions [65]. Further, Chen et al. revealed that the novelty, understandability, and interestingness of travel blog contents influence behavioral intentions through blog-usage intentions [66].

Analysis of the above literature shows that usage intentions may positively affect travel intentions and play a mediating role. Thus, we develop the following hypothesis:

Hypothesis 9 (H9). Usage intentions for WOAs positively affect travel intentions regarding travel-related WOAs. 
Based on the above literature review and the development of hypotheses, the theoretical model is shown in Figure 1. The theoretical model comprised six variables: information motivation, self-service motivation, entertainment motivation, social motivation, usage intentions, and travel intentions. According to the U\&G theory, the four types of motivations mentioned above correspond to four types of user gratification, namely: information gratification, self-service gratification, entertainment gratification, and social gratification.

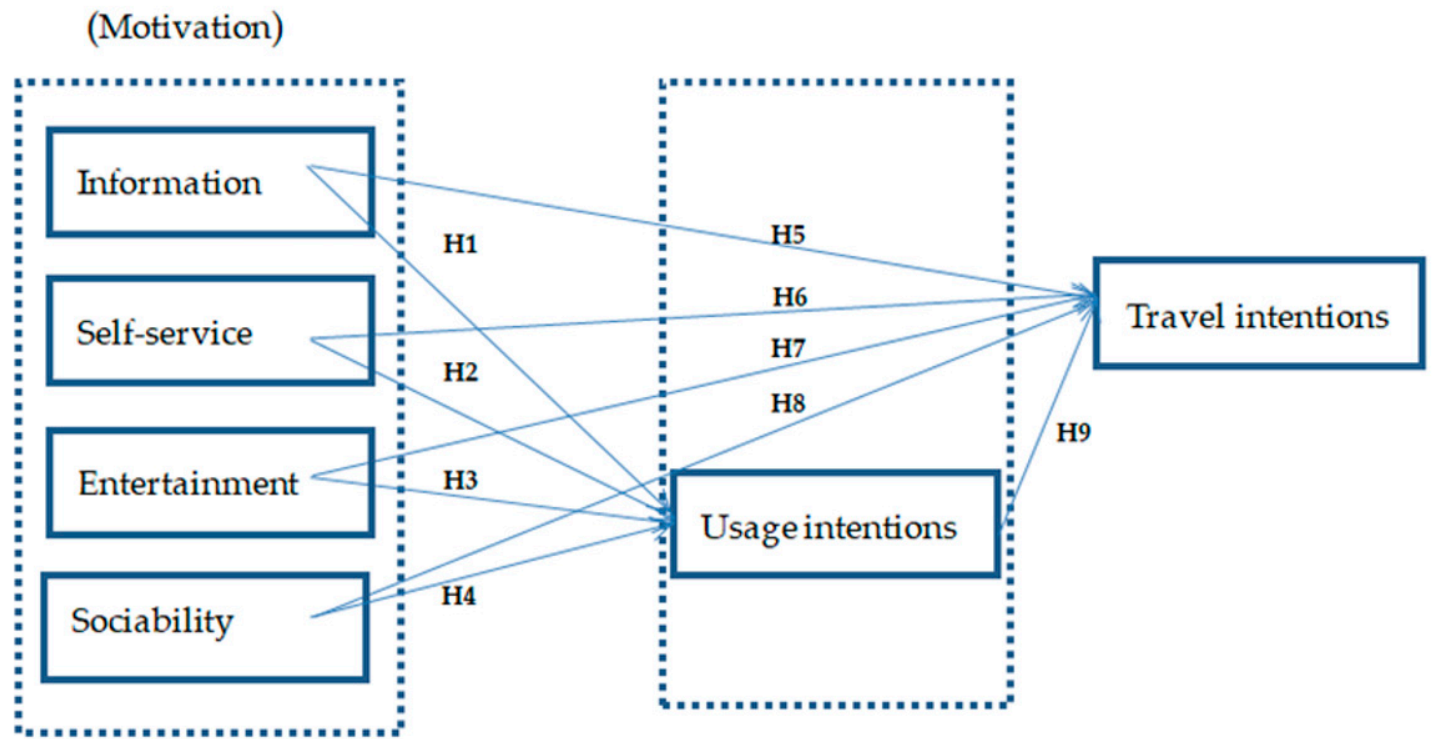

Figure 1. Theoretical Model Diagram.

\section{Research Methodology}

\subsection{Research Setting}

There are abundant tourism resources in China's Fujian Province, with three UNESCO World Heritage sites (Wuyi Mountain, Fujian Earth Building and Danxia) two UNESCO Global Geoparks (Taining and Ningde), 10 national 5A tourist attractions, 10 national geological parks, 15 national nature reserves, 29 national forest parks, 137 national key cultural relic protection units, and 4 national historical and cultural cities [67]. It is one of the most important tourism provinces in China.

In recent years, the tourism market in Fujian has shown year-on-year growth. In 2018, Fujian achieved total tourism revenue of 663.46 billion yuan (amount to approximately 94.61 billion dollars), an increase of $30.5 \%$. It received 9.01 million inbound tourists, an increase of $16.2 \%$ over the previous year. Revenue reached $\$ 9.09$ billion yuan (amount to approximately 1.27 billion dollars). The number of domestic tourists received was 451.39 million, an increase of $20.3 \%$; domestic tourism income was 603.30 billion yuan, up $32.0 \%$ [68].

This study selected the "Fujian Tourism" WOA (fjta12301) for this research, based on the following rationale: first, Fujian is a core area of China's "21st Century Maritime Silk Road" initiative (a Chinese strategic initiative to increase investment and foster collaboration) and enjoys an abundance of tourism resources; second, it is China's first national ecological civilization pilot zone (that is, under a plan to explore new practices and conduct reforms to preserve the ecology and protect the environment), with "Refreshing Fujian" being the slogan of Fujian tourism [69]; third, the "Fujian Tourism" WOA is not only an important online platform for external officially regarding Fujian-related tourism information, but is also a brand new official interactive platform. 


\subsection{Questionnaire Design and Data Collection}

\subsubsection{Questionnaire Design}

A questionnaire survey was used to gather the necessary data for model validation. Relevant previous studies were examined in order to design and adapt model dimensions and items for the present study. Appendix A shows the sources of the items used. The initial questionnaire was modified based on two experts' opinions (that is, those of a full professor and associate professor in the tourism studies field) before testing. Then, five master's students majoring in tourism studies were recruited to read the questionnaire and identify any ambiguity. The results showed that WOA users would have a good understanding of the questionnaire instructions and items. The official questionnaire was then finalized.

The questionnaire was divided into three parts. The first section comprised the questionnaire instructions. The second section concerned the various variables of the research framework, including motivation and gratification variables (information, self-service, entertainment, and sociability) and usage and travel intentions associated with the travel-related WOAs; each item was scored using a seven-point Likert scale, with " 1 " representing "strongly disagree" and "7" representing "strongly agree." Finally, the third section concerned the respondents' demographic information (gender, age, education level, marital status, and monthly personal income), their daily screen time on WeChat, their history of WeChat usage, and their number of WeChat friends (please refer to Appendix A for the questionnaire items and their sources).

\subsubsection{Data Collection}

The questionnaire was published on Sojump (www.Sojump.com), the most popular online survey tool in China [70]. Many recent research studies have employed Sojump to solicit survey responses [56,71,72].

The interviewees who were addressed were randomly selected from the members who had used the "Fujian Tourism" WOA (fjta12301). They were of different ages, identities, occupations, and regions. Respondents provided their answers via computer or cellphone.

Completed respondents were collected via Sojump for statistical analysis, with a total of 741 retrieved from November 6 to 23, 2018. After excluding respondents- with repetitive IP addresses and those completed in less than 120 seconds or in more than 1800 seconds, a total of 729 valid questionnaires were eventually obtained.

\subsubsection{Data Processing and Analytical Methods}

Validity testing of the questionnaire was initially conducted using Cronbach's $\alpha$. After verifying that the questionnaire possessed sufficient validity, exploratory factor analysis (EFA) was then performed to construct the dimensions of the motivation and gratification variables. Afterward, Amos 24.0 software (IBM, Somers, NY, USA, version 24.0) was employed to perform confirmatory factor analysis (CFA) and to determine the goodness-of-fit, convergent validity, and discriminant validity of the measurement model. Finally, structural equation modeling was conducted, and bootstrapping was used to test the mediation effects of the model.

\section{Results}

\subsection{Sample Characteristics}

Table 1 shows the demographic data of the surveyed sample. Among the 729 respondents, $59 \%$ were females; the majority were unmarried (51.9\%) and had a high level of education $(62.3 \%$ had a bachelor's degree). In addition, $74.3 \%$ of the respondents spent over two hours daily on WeChat, and $77 \%$ had been using WeChat for over two years; $39.8 \%$ had a monthly income that exceeded 5000 yuan (equivalent to approximately $\$ 728$ ), and $24.7 \%$ had over $200 \mathrm{WeChat} \mathrm{friends.}$ 
Table 1. Summary of demographic statistics $(n=729)$.

\begin{tabular}{|c|c|c|}
\hline Gender & $n$ & $\%$ \\
\hline male & 299 & 41.0 \\
\hline female & 430 & 59.0 \\
\hline \multicolumn{3}{|l|}{ Age } \\
\hline$\leq 20$ & 119 & 16.3 \\
\hline$\leq 30$ & 370 & 50.8 \\
\hline$\geq 30$ & 240 & 32.9 \\
\hline \multicolumn{3}{|l|}{ Marriage } \\
\hline unmarried & 378 & 51.9 \\
\hline married & 345 & 47.3 \\
\hline else & 6 & 0.80 \\
\hline \multicolumn{3}{|l|}{ Education } \\
\hline junior & 228 & 31.3 \\
\hline undergraduate & 454 & 62.3 \\
\hline graduate & 47 & 6.40 \\
\hline \multicolumn{3}{|c|}{ Individual monthly income (Renminbi, or RMB) } \\
\hline$\leq 2000$ & 204 & 28.0 \\
\hline$>2000$ and $\leq 5000$ & 235 & 32.2 \\
\hline$>5000$ & 290 & 39.8 \\
\hline \multicolumn{3}{|l|}{ Daily time spent on WeChat } \\
\hline$>1 \mathrm{~h}$ and $\leq 2 \mathrm{~h}$ & 187 & 25.7 \\
\hline$>2 \mathrm{~h}$ and $\leq 3 \mathrm{~h}$ & 254 & 34.8 \\
\hline$>3 \mathrm{~h}$ & 288 & 39.5 \\
\hline \multicolumn{3}{|c|}{ How long have you used WeChat } \\
\hline$\leq 1$ year & 55 & 7.50 \\
\hline$>1$ year and $\leq 2$ years & 113 & 15.5 \\
\hline$>2$ years & 561 & 77.0 \\
\hline \multicolumn{3}{|c|}{ How many friends do you have on WeChat } \\
\hline$\leq 50$ & 93 & 12.8 \\
\hline$>50$ and $\leq 100$ & 184 & 25.2 \\
\hline$>101$ and $\leq 150$ & 165 & 22.6 \\
\hline$>151$ and $\leq 200$ & 107 & 14.7 \\
\hline$>200$ & 180 & 24.7 \\
\hline
\end{tabular}

The results of this demographic data are consistent with the results of the 44th China Internet Network Development Report of the China Internet Network Information Center (CNNIC), as well as with the entire Internet user sample database. The report shows that as of June 2019, the largest group of Internet users in China were students, accounting for $26.0 \%$; regarding age structure, as of June 2019, Internet users aged $10-39$ accounted for $65.1 \%$ of all internet users, among which those aged 20-29 accounted for $24.6 \%$. Income structure shows that by June 2019 , netizens with a monthly income of 2001-5000 yuan accounted for more than one-third of the total, that is, $33.4 \%$. All this is consistent with our demographic data [73].

\subsection{Analysis of the Measurement Model}

First, reliability and validity testing were conducted on the questionnaire, yielding a Cronbach's $\alpha$ value of 0.862 . According to Kline, a reliability coefficient of over 0.8 is very satisfactory [74]. The 12 items regarding motivation and gratification then underwent EFA; analytical results revealed that the factors influencing usage and travel intentions could be classified into four dimensions, namely, information motivation, self-service motivation, entertainment motivation, and social motivation. Then, 
the remaining five items, which involved usage and travel intentions, also underwent factor analysis. The results showed that cross-loading occurred for the item "I will recommend this travel-related WOAs to my family or friends." Hair et al. suggested that any item that has a significant correlation with two or more factors should be eliminated, as it may imply a poor item design [75]. Thus, this item was eliminated, and the finalized questionnaire was used as the official version for CFA validation.

During validation, Amos version 24.0 was employed to test the goodness-of-fit, convergent validity, and discriminant validity of the model. Table 2 illustrates the goodness-of-fit results $(\chi 2 / \mathrm{df}=3.280$; $\mathrm{GFI}=0.951 ; \mathrm{RMSEA}=0.056 ; \mathrm{CFI}=0.941 ; \mathrm{IFI}=0.942 ; \mathrm{TLI}=0.920$ ). During the CFA, composite reliability (CR) was used to determine the internal consistency of the model; all CRs were consequently found to exceed 0.6 , which indicated satisfactory reliability [72]. The convergent validity was measured using factor loadings and average variance extracted (AVE) [75,76]. All factor loadings were consequently found to exceed 0.5 , which implied a relatively high level of convergent validity. AVE reflects the average variance of item loading on a construct. Each of the constructs had an AVE value of 0.5, which indicated satisfactory convergent validity. Table 3 summarizes the statistical outcomes of the CFA.

Table 2. Fit indices for the measurement model.

\begin{tabular}{cccc}
\hline Model Fit Measures & Model Fit Criterion & Index Value & Good Model Fit(Y/N) \\
\hline Absolute fit indices RMSEA, Root Mean & $<0.08$ & 0.056 & $\mathrm{Y}$ \\
Square Error of Approximation & $>0.9$ & 0.951 & $\mathrm{Y}$ \\
GFI, Goodness of Fit Index & $<4.0$ & 3.280 & $\mathrm{Y}$ \\
CMIN/DF, Chi Square/Degree of Freedom & & & $\mathrm{Y}$ \\
Incremental fit indices & $>0.9$ & 0.941 & $\mathrm{Y}$ \\
CFI, Comparative Fit Index & $>0.9$ & 0.942 & $\mathrm{Y}$ \\
IFI, Incremental Fit Index & $>0.9$ & 0.920 & \\
TLI, Tucker-Lewis Index & & & \\
\hline
\end{tabular}

Table 3. Statistical outcomes of the confirmatory factor analysis.

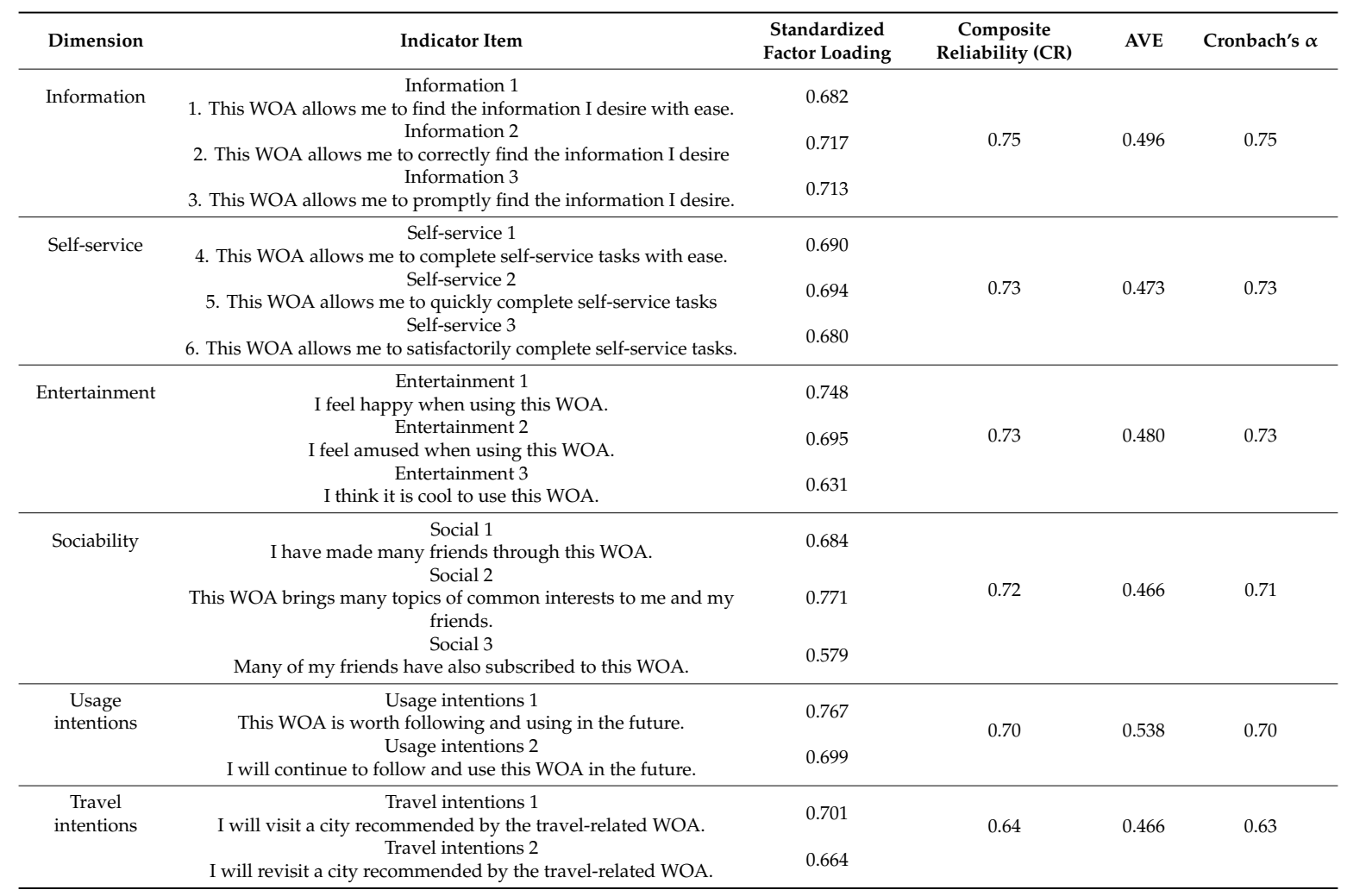


In terms of discriminant validity, Fornell and Larcker suggested that the AVE of a dimension should be larger than the square of the correlation between any two constructs [77]. The results for the present data illustrated that for all constructs the AVE values (the diagonal elements in Table 4) exceeded the square of the correlation between any two constructs (the off-diagonal elements in Table 4); hence, discriminant validity was supported. Based on the above, we determined that the measurement model possessed sufficient goodness-of-fit and satisfactory reliability, convergent validity, and discriminant validity.

Table 4. Discriminant validity.

\begin{tabular}{ccccccc}
\hline & Information & Self-Service & Entertainment & Sociability & Usage Intentions & Travel Intentions \\
\hline Information & 0.704 & & & & & \\
Self-service & $0.505^{* *}$ & 0.688 & & & & \\
Entertainment & $0.379^{* *}$ & $0.405^{* *}$ & 0.693 & & & \\
Sociability & $0.261^{* *}$ & $0.244^{* *}$ & $0.460^{* *}$ & 0.683 & & \\
Usage intentions & $0.350^{* *}$ & $0.306^{* *}$ & $0.434^{* *}$ & $0.475^{* *}$ & 0.733 & \\
Travel intentions & $0.321^{* *}$ & $0.249^{* *}$ & $0.353^{* *}$ & $0.292^{* *}$ & $0.353^{* *}$ & 0.683 \\
\hline
\end{tabular}

The diagonal values are the average variance explained (square root of AVE); the off-diagonal values are the correlation coefficients with other constructs. ${ }^{* *}$ significantly correlated at the 01 level (two-tailed); ${ }^{*}$ significantly correlated at the 0.05 level (two-tailed).

\subsection{Analysis of the Structural Model}

The structural model was validated using Amos version 24.0. The goodness-of-fit indices $(\chi 2 / \mathrm{df}=3.280 ; \mathrm{RMSEA}=0.056 ; \mathrm{GFI}=0.951 ; \mathrm{CFI}=0.941 ; \mathrm{IFI}=0.942 ; \mathrm{TLI}=0.920)$ implied a good model fit. The structural model was then evaluated to validate the hypothesized relationships. The results showed that the standardized path coefficients were statistically significant. Information motivation ( $B=0.190, p<0.01)$, entertainment motivation $(B=0.242, p<0.01)$, and social motivation $(B=0.406$, $p<0.001$ ) were found to have significantly positive effects on usage intentions, which indicated that they were important predictors of usage intentions. Thus, $\mathrm{H} 1, \mathrm{H} 3$, and $\mathrm{H} 4$ were statistically validated. Similarly, information motivation $(B=0.241, p<0.01)$ and entertainment motivation $(B=0.217, p<0.01)$ also showed significant positive effects on travel intentions, which identified them as important predictors of travel intentions. Thus, $\mathrm{H} 5$ and $\mathrm{H} 7$ were statistically validated. Finally, usage intentions $(B=0.262, p<0.01)$ significantly influenced travel intentions, which implied that the former is a factor that influences the latter. H9, therefore, was statistically supported. Figure 2 and Table 5 present the results of the hypothesis testing and path coefficients.

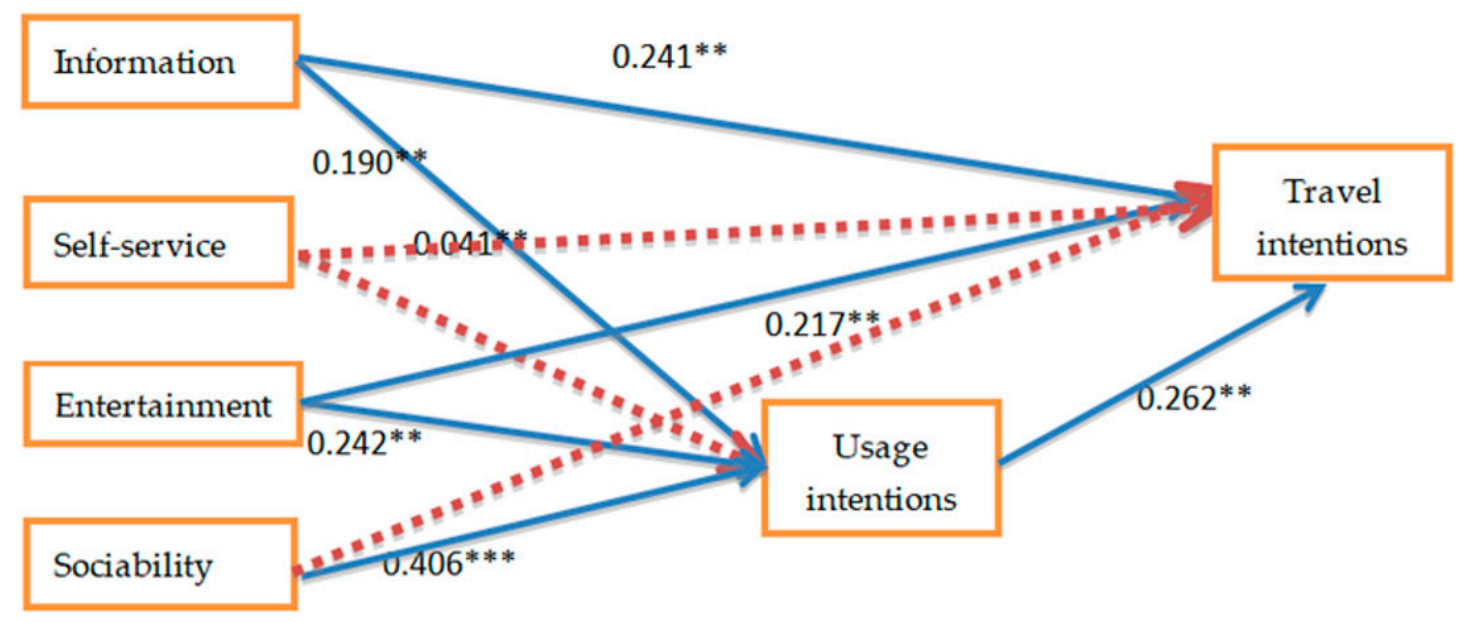

Figure 2. Model Verification Results. Note: ${ }^{* *} p=0.01{ }^{* * *} p=0.001$ 
Table 5. Path results of the structural model.

\begin{tabular}{cccc}
\hline Hypotheses Paths & Standardized Coefficient & t-Value & Yes or No \\
\hline H1: Information $\rightarrow$ usage intentions & $0.190^{* *}$ & $2.568^{* *}$ & YES \\
H2: Self-service $\rightarrow$ usage intentions & 0.032 & 0.404 & NO \\
H3: Entertainment $\rightarrow$ usage intentions & $0.242^{* *}$ & $2.971^{* *}$ & YES \\
H4: Sociability $\rightarrow$ usage intentions & $0.406^{* * *}$ & $5.811^{* * *}$ & YES \\
H5: Information $\rightarrow$ travel intentions & $0.241^{* *}$ & $2.794^{* *}$ & YES \\
H6: Self-service $\rightarrow$ travel intentions & -0.041 & -0.461 & NO \\
H7: Entertainment $\rightarrow$ travel intentions & $0.217^{* *}$ & $2.320^{* *}$ & YES \\
H8: Sociability $\rightarrow$ travel intentions & 0.049 & 0.592 & NO \\
H9: Usage intentions $\rightarrow$ travel intentions & $0.262^{* *}$ & $2.990^{* *}$ & YES \\
\hline
\end{tabular}

Note: ${ }^{* *} p<0.01,{ }^{* * *} p<0.001$.

\subsection{Testing for Mediation Effect}

The mediation effect of the model was tested through bootstrapping. As the calculated bootstrap confidence interval (CI) did not include zero, we concluded that there was an indirect effect $[77,78]$. The 95\% bias-corrected CI and 95\% percentile CI were calculated using Amos 24.0 and a bootstrapping approach with 2000 iterations (Table 6).

Table 6. Testing for mediation effect.

\begin{tabular}{|c|c|c|c|c|c|c|}
\hline \multirow[t]{2}{*}{ Type of Effect } & \multirow{2}{*}{ Path } & \multirow{2}{*}{$\begin{array}{l}\text { Standardized } \\
\text { Effect Size }\end{array}$} & \multicolumn{2}{|c|}{$\begin{array}{c}\text { Bias-Corrected } \\
95 \% \mathrm{CI}\end{array}$} & \multicolumn{2}{|c|}{$\begin{array}{c}\text { Percentile } \\
95 \% \text { CI }\end{array}$} \\
\hline & & & Lower & Upper & Lower & Upper \\
\hline Total effect & Information—travel intentions & 0.291 & 0.115 & 0.463 & 0.116 & 0.465 \\
\hline Direct effect & Information-travel intentions & 0.241 & 0.044 & 0.418 & 0.052 & 0.430 \\
\hline Indirect effect & $\begin{array}{c}\text { Information-usage } \\
\text { intentions-travel intentions }\end{array}$ & 0.050 & 0.005 & 0.135 & 0.003 & 0.116 \\
\hline Total effect & Entertainment-travel intentions & 0.280 & 0.078 & 0.482 & 0.079 & 0.487 \\
\hline Direct effect & Entertainment- travel intentions & 0.217 & -0.07 & 0.434 & -0.004 & 0.439 \\
\hline Indirect effect & $\begin{array}{l}\text { Entertainment-usage } \\
\text { intentions-travel intentions }\end{array}$ & 0.063 & 0.010 & 0.174 & 0.003 & 0.151 \\
\hline Total effect & Sociability-travel intentions & 0.155 & -0.020 & 0.323 & -0.023 & 0.318 \\
\hline Direct effect & Sociability-travel intentions & 0.049 & -0.183 & 0.236 & -0.173 & 0.244 \\
\hline Indirect effect & $\begin{array}{c}\text { Sociability-usage } \\
\text { intentions-travel intentions }\end{array}$ & 0.106 & 0.012 & 0.239 & 0.009 & 0.225 \\
\hline
\end{tabular}

Table 6 shows that the total effect of information on travel intentions was 0.291 , which indicated that the path model had a significant total effect; meanwhile, the direct effect of information on travel intentions was 0.241 , which indicated a significant direct effect; finally, the indirect effect of information on travel intentions through usage intentions was 0.050 , which implied a significant indirect effect. Thus, usage intentions partially mediate the effect of information on travel intentions.

The total effect of entertainment on travel intentions was 0.487 , which indicated that the total effect of the path model was significant. Meanwhile, the direct effect of entertainment on travel intentions was 0.049 , which implied an insignificant direct effect; finally, the indirect effect of entertainment on travel intentions through usage intentions was 0.151 , denoting a significant indirect effect. Thus, usage intentions fully mediate the effect of entertainment on travel intentions.

Given that the total effect of social interaction on travel intentions was 0.155 , the total effect of the path model was insignificant.

In summary, usage intentions mediate the model comprising factors influencing WOAs users' travel intentions. More specifically, they partially mediate the relationship between information motivation and travel intentions while fully mediating that between entertainment motivation and travel intentions. 


\section{Discussion}

This is a preliminary study that aimed to examine the effects of information, self-service, entertainment, and social motivations have on usage intentions for travel-related WOAs and, consequently, on users' travel intentions. This study also sought to evaluate the relationship between users' usage intentions and travel intentions in relation to travel-related WOAs. The results validated the positive effects of information, entertainment, and social motivations on usage intentions regarding travel-related WOAs, the positive effects of information and entertainment motivations on WOA users' travel intentions, and the positive effects of users' usage intentions on their travel intentions.

\subsection{Factor Influencing WOAs Users' Usage Intentions}

Analysis of the direct effect of psychological gratification types (information, entertainment, and social interaction) on usage intentions showed that social motivation $(0.406)$ is the main factor influencing usage intentions. This verified $\mathrm{H} 4$, and past research has also pointed out that one of the main motivations for people to use social media is sociality $[19,35,78]$. In regard to social interaction, WOAs allows users to easily connect with strangers and make new friends. The significant positive influence of sociability on user intentions identified in the present study accords with the findings of Chang and Zhu (2011), who indicated that social interactions are crucial motivating factors behind WOA users' usage behaviors [14]. Thus, actively encouraging WOA users to interact with their friends is an effective method of advancing the development of WOAs.

Information (0.190) and entertainment (0.242) are secondary influencing factors regarding usage intentions, which validates the hypothesis $\mathrm{H} 1$ and $\mathrm{H} 3$. These findings are consistent with the previous research [79-82]. Entertainment has a positive effect on users' intention [83], but due to platform characteristics of WOAs, the main function is a content push, which is a passively received communication mode. Interaction is poor, and it is not as good as immersive media such as WeChat, Weibo, or online games.

\subsection{Effect on Travel Intentions}

Regarding the direct effect of psychological gratification types (information and entertainment) on travel intentions, information (0.241) was found to be the main factor influencing travel intentions, followed by entertainment ( 0.217$)$; social gratifications do not influence travel intentions. The positive effect of information on users' travel intentions verifies hypothesis $\mathrm{H} 5$ and is consistent with previous research $[66,84,85]$. Wen and Huang (2019) analyzed the motivations of 348 visitors and found that unique seeking information predicted travel intentions [50].

Entertainment motivation (0.217) exerts a positive influence on travel intentions. H7 was validated, in line with previous research by Chiu and Yang [86]. Usage intentions influence travel intentions (0.262), so H9 was also validated. Thus, entertainment ultimately influences users' travel intentions, but this influence is fully mediated by usage intentions, matching the findings of Huang (2008) [28]. Unlike previous findings by Aluri et al. (2016) demonstrating that sociality affects behavior intentions [87], this result shows that sociality does not affect the user's travel intentions, which does not support H8. Nevertheless, travel intentions can be effectively reinforced by enhancing the amusement and entertainment facilitated by WOAs.

\subsection{Self-Service Motivation}

Self-service factors have no significant effect on either usage intentions or travel intentions; that is, $\mathrm{H} 2$ and $\mathrm{H} 6$ are not supported. Generally speaking, all travel-related WOAs now possess a reservation feature. WOAs also offer other self-service features, such as audio services, navigation maps, and membership offers [88]. However, the present study found that these features do not influence either usage intentions or travel intentions. It is recommended, therefore, that WOAs reduce the focus on these features. The reason for these features' lack of influence, as inferred by the author, is that 
these self-services can all be substituted by specialized platforms or media. Use of navigation maps, for example, may be undermined by users' preference for more dedicated applications such as Gaode Maps, Baidu Maps, and Google Maps.

These findings underline the dominant role of social interaction for WOAs users' usage intentions, the dominant role of information for WOA users' travel intentions, and the mediating effect of usage intentions on travel intentions.

Our study aims to equip marketing analysts and executives with insights that can be implemented in the future. According to the results, the travel-related WOAs will be designed to be more entertaining. Reviews, photos, and videos shared via WOAs or online platforms motivate users to visit a place, attend an event, or buy a product. The real-time access to relevant tips and guides, traveling instructions, or inspirational photos/videos has ultimately changed the way users plan an activity, which almost is to increase tourists [89]. Furthermore, big data from the WOAs and mobile device signaling elucidates wider patterns of tourist movement, as applied to forecast travel demands and sustainable management of a destination [90].

\section{Conclusions and Limitations}

There are three implications of the research ranging from theory to practice for sharpening the skills of tourism managers.

\subsection{Improve the Social Design of Interfaces in Order to Enhance Usage Intentions}

This study has shown that social gratification constitutes the foremost factor influencing WOA users' usage intentions and serves as a means by which travel-related WOAs can stay connected with users (who can meet new friends through traveling and interact through the WOAs). Regardless of how such relationships are formed, travel-related WOAs should preferably establish features for interacting and socializing in order to better enhance usage intentions. For instance, they could make announcements through notifications and promote a transition from one-way communication with users to many-way interactions involving relevant parties.

\subsection{Enhancing Travel Intentions by Enriching the Content Published}

This study found that information is the primary factor influencing users' travel intentions, and that they can also be enhanced by a high level of entertainment. Hence, WOA managers should publish professional information that is useful for users, such as information that can help travelers make informed travel-related decisions, enhancing their usage intentions. WOAs can also enrich the content published via various other means. For instance, travel information could be presented in the form of building an information recommender system for users according to the similarities in groups of people [91].

\subsection{Reducing Focus on Self-Service Features}

Travel-related WOAs offer self-services including ticket reservations (entry tickets and other reservations), navigation maps, online shopping, online customer services, and member centers [63]. Despite their appeal to users, however, this study proved that they fail to enhance users' usage and travel intentions. Thus, travel-related WOAs should remove some or all of these features and focus on the advantages of the WOA design, which relate to information, entertainment, and social gratification. Efforts should be made to enhance features such as information regarding tourist attractions, characteristic activities and attractions, recommended itineraries, nearby services, city guides, audio guides, and reviews and comments, as well as opportunities for interactions among travelers, as such features gratify users' information, entertainment, and social needs.

As with all studies, the present study has some limitations. First, as it focused on travel-related WOAs in China, the results might be limited to the Chinese population. Caution should be exercised when extrapolating the results to other countries and other social media; and future studies should 
take into consideration the effects of cultural differences on usage intentions in the social media context. Second, as this study adopted Sojump as the source of its sample, the responses might exhibit randomness, which could have led to bias in the results. Therefore, this study merely represents an exploratory attempt, and despite the satisfactory outcomes of the structural equation model, a more in-depth investigation is still warranted. Third, this study illustrated usage and travel motivations associated with the use of travel-related WOAs using various dimensions; future studies on WOAs should attempt to validate the factors that influence usage and travel intentions by exploring more combinations of motivations.

Author Contributions: Conceptualization and methodology, B.-S.L. and Y.-J.L.; writing-review and editing, B.-S.L., conceptualization, methodology, data curation, and writing-original draft preparation, Y.W. All authors read and approved the manuscript.

Funding: This research was funded by Internet Innovation Research Center-The College's Research Base of Humanities and Social Science in Fujian Province, Minjiang University (Grant No. IIRC20190106), and Young and Middle-aged Teachers' Educational Research Project of Fujian Province (Grant No. JAS160415).

Conflicts of Interest: The authors declare no conflict of interest.

\section{Appendix A Constructs and Items}

Information motivation and gratification (I) [23]

I1: This WOAs allows me to find the information I desire with ease.

I2: This WOA allows me to find the exact information I desire.

I3: This WOA allows me to promptly find the information I desire.

Self-service motivation and gratification (S-S) [92]

S-S1: This WOA allows me to complete self-service tasks with ease.

S-S2: This WOA allows me to quickly complete self-service tasks.

S-S3: This WOA allows me to satisfactorily complete self-service tasks.

Entertainment motivation and gratification (E) [93]

E1: I feel happy when using this WOA.

E2: I feel amused when using this WOA.

E3: I think it is cool to use this WOA.

Social motivation and gratification (S) $[22,35]$

S1: I have made many friends through this WOA.

S2: This WOA has many topics of common interest for me and my friends.

S3: Many of my friends have also subscribed to this WOA.

Usage intention (UI) [94,95]

UI1: This WOA is worth following and using in the future.

U12: I will continue to follow and use this WOA in the future.

U13: I will recommend this travel-related WOA to my family or friends.

Travel intention (TI) [96]

TI1: I will visit a city recommended by the travel-related WOA.

TI2: I will revisit a city recommended by the travel-related WOA.

\section{References}

1. Tencent. Communications and Social. Available online: https://www.tencent.com/en-us/business.html (accessed on 30 December 2019).

2. $\mathrm{Xu}, \mathrm{J} . ;$ Kang, Q.; Song, Z.; Clarke, C.P. Applications of mobile social media: WeChat among academic libraries in China. J. Acad. Librariansh. 2015, 41, 21-30. [CrossRef]

3. Yu, X.; Zhao, T.; Tong, S. Development Report on China's WeChat in 2014. In Development Report on China's New Media; Springer: Singapore, 2017; pp. 63-78. 
4. WeChat Demographics and Insights. WeChat Data, Insights and Statistics: User Profile, Behaviours, Usages, Market Trends. Available online: https://wechatwiki.com/wechat-resources/wechat-data-insight-trendstatistics (accessed on 2 July 2020).

5. Tang, C.; Li, X.; Gu, H. Concentrate on tourism scholars at home and abroad to build the China Youth Tourism Forum. Resour. Sci. 2019, 41, 415.

6. Ministry of Culture and Tourism. Basic Situation of the Tourism Market in 2019. Available online: https://www.mct.gov.cn/whzx/whyw/202003/t20200310_851786.htm (accessed on 10 March 2020).

7. Tang, M. Research on Wechat Marketing Strategy of Enterprises which is based on the SICAS Model. Int. J. Bus. Soc. Sci. 2014, 5, 213-217.

8. Kim, D.; Kim, S. The role of mobile technology in tourism: Patents, articles, news, and mobile tour appreviews. Sustainability 2017, 9, 2082. [CrossRef]

9. Mariani, M.M.; Di Felice, M.; Mura, M. Facebook as a destination marketing tool: Evidence from Italian regional Destination Management Organizations. Tour. Manag. 2016, 54, 321-343. [CrossRef]

10. Liang, X.; Yang, Y. An experimental study of Chinese tourists using a company-hosted WeChat official account. Electron. Commer. Res. Appl. 2018, 27, 83-89. [CrossRef]

11. Lu, J.; Mao, Z.; Wang, M.; Hu, L. Goodbye maps, hello apps? Exploring the influential determinants of travel app adoption. Curr. Issues Tour. 2015, 18, 1059-1079. [CrossRef]

12. Sun, F.; Wang, T. Somehospital Emergency triage group makes an attempt to extend medical humanistic service around the construction of Wechat official account. Chin. J. Pract. Nurs. 2017, 33, 2230-2231.

13. Tu, S.; Yan, X.; Jie, K.; Ying, M.; Huang, C. WeChat: An applicable and flexible social app software for mobile teaching. Biochem. Mol. Biol. Educ. 2018, 46, 555-560. [CrossRef]

14. Xu, S.; Hemminger, B.M. Lessons learned from the investigation of academic WeChat official accounts. In Proceedings of the iConference 2019, Washington, DC, USA, 31 March 2019.

15. Walkthechat. WeChat Impact Report 2018. Available online: http://www.199it.com/archives/725398.html (accessed on 18 May 2018).

16. Xing, L.; Deng, K.; Wu, H.; Xie, P.; Gao, J. Behavioral Habits-Based User Identification Across Social Networks. Symmetry 2019, 11, 1134. [CrossRef]

17. Tian, M.; Xu, G. Exploring the determinants of users' satisfaction of WeChat official accounts. In Proceedings of the 2017 3rd International Conference on Information Management (ICIM) IEEE, Chengdu, China, 21-23 April 2017; pp. 362-367.

18. Shah, D.V.; McLeod, J.M.; Yoon, S.H. Communication, context, and community: An exploration of print, broadcast, and Internet influences. Commun. Res. 2001, 28, 464-506. [CrossRef]

19. Shao, C.; Kwon, K.H. Clicks intended: An integrated model for nuanced social feedback system uses on Facebook. Telemat. Inform. 2019, 39, 11-24. [CrossRef]

20. Pal, A. Motivations of Individuals Participating in Social Media: A Cultural Perspective. J. Mod. Account. Audit. 2018, 14, 315-332.

21. Zhang, L.; Jung, E.H. WeChatting for health: An examination of the relationship between motivations and active engagement. Health Commun. 2019, 34, 1764-1774. [CrossRef]

22. Chang, Y.P.; Zhu, D.H. Understanding social networking sites adoption in China: A comparison of pre-adoption and post-adoption. Comput. Hum. Behav. 2011, 27, 1840-1848. [CrossRef]

23. Kim, Y.; Sohn, D.; Choi, S.M. Cultural difference in motivations for using social network sites: A comparative study of American and Korean college students. Comput. Hum. Behav. 2001, 27, 365-372. [CrossRef]

24. Zhang, L.; Pentina, I. Motivations and usage patterns of Weibo. Cyberpsychol. Behav. Soc. Netw. 2012, 15, 312-317. [CrossRef]

25. Gan, C.; Wang, W. Uses and gratifications of social media: A comparison of microblog and WeChat. J. Syst. Inf. Technol. 2015, 17, 351-363. [CrossRef]

26. Pennington-Gray, L.; Schroeder, A.; Kaplanidou, K.K. Examining the influence of past travel experience, general web searching behaviors, and risk perceptions on future travel intentions. IJSSTH 2011, 1, 64-89.

27. Mendes-Filhoa, L.; Corrêab, C.; Mangueirab, M. Online Travel Reviews on Mobile Applications when making travel plans: Uses and Gratifications perspectives. Inf. Commun. Technol. Tour. 2015, 6, 59-72.

28. Huang, E. Use and gratification in e-consumers. Internet Res. 2008, 18, 405-426. [CrossRef]

29. Luo, X. Uses and gratifications theory and e-consumer behaviors: A structural equation modeling study. J. Interact. Advert. 2002, 2, 34-41. [CrossRef] 
30. Rubin, A.M. The effect of locus of control on communication motivation, anxiety, and satisfaction. Commun. Q. 1993, 41, 161-171. [CrossRef]

31. Rubin, A.M. Uses-and-gratifications perspective on media effects. In Media Effects; Routledge: New York, NY, USA, 2009; pp. 181-200.

32. Kowatsch, T.; Maass, W. In-store consumer behavior: How mobile recommendation agents influence usage intentions, product purchases, and store preferences. Comput. Hum. Behav. 2010, 26, 697-704. [CrossRef]

33. Jung, T.; Youn, H.; McClung, S. Motivations and self-presentation strategies on Korean-based "Cyworld" weblog format personal homepages. Cyberpsychol. Behav. 2007, 10, 24-31. [CrossRef] [PubMed]

34. Wei, R. Motivations for using the mobile phone for mass communications andentertainment. Telemat. Inform. 2008, 25, 36-46. [CrossRef]

35. Raacke, J.; Bonds-Raacke, J. MySpace and Facebook: Applying the uses and gratifications theory to exploring friend-networking sites. Cyberpsychol. Behav. 2008, 11, 169-174. [CrossRef]

36. Brandtzæg, P.B.; Heim, J. Why people use social networking sites. In Proceedings of the International Conference on Online Communities and Social Computing, San Diego, CA, USA, 19-24 July 2009; pp. $143-152$.

37. Li, H.; Liu, Y.; Xu, X.; Heikkilä, J.; Van Der Heijden, H. Modeling hedonic is continuance through the uses and gratifications theory: An empirical study in online games. Comput. Hum. Behav. 2015, 48, 261-272. [CrossRef]

38. Liu, I.L.; Cheung, C.M.; Lee, M.K. User satisfaction with microblogging: Information dissemination versus social networking. J. Assoc. Inf. Sci. Technol. 2016, 67, 56-70. [CrossRef]

39. Zhang, C.B.; Li, Y.N.; Wu, B.; Li, D.J. How WeChat can retain users: Roles of network externalities, social interaction ties, and perceived values in building continuance intention. Comput. Hum. Behav. 2017, 69, 284-293. [CrossRef]

40. Hwang, H.S.; Cho, J. Why Instagram? Intention to continue using Instagram among Korean college students. Soc. Behav. Personal. Int. J. 2018, 46, 1305-1315. [CrossRef]

41. Zhu, W. Analysis of the Application of Big Data in Intelligent Tourism Mode. In Proceedings of the 20164 th International Conference on Electrical Electronics Engineering and Computer Science (ICEEECS 2016), Jinan, China, 15-16 October 2016.

42. Lin, H.F.; Chen, C.H. Combining the Technology Acceptance Model and Uses and Gratifications Theory to examine the usage behavior of an Augmented Reality Tour-sharing Application. Symmetry 2017, 9, 113. [CrossRef]

43. Lu, Y.; Jin, C.; Qiu, J.; Jiang, P. Using a hybrid multiple-criteria decision-making technique to identify key factors influencing microblog users' diffusion behaviors in emergencies: Evidence from generations born after 2000. Symmetry 2019, 11, 265. [CrossRef]

44. Dann, G.M. Tourist motivation an appraisal. Ann. Tour. Res. 1981, 8, 187-219. [CrossRef]

45. Iso-Ahola, S.E.; Allen, J.R. The dynamics of leisure motivation: The effects of outcome on leisure needs. Res. Q. Exerc. Sport 1982, 53, 141-149. [CrossRef] [PubMed]

46. Kotler, P. Marketing Management-Analysis, Planning, Implementation, and Control; Prentice Hall: London, UK, 1994.

47. Armstrong, G.; Adam, S.; Denize, S.; Kotler, P. Principles of Marketing; Pearson: Camberwell, Australia, 2014.

48. Prayag, G.; Chen, N.; Del Chiappa, G. Domestic tourists to Sardinia: Motivation, overall attitude, attachment, and behavioural intentions. Anatolia 2018, 29, 84-97. [CrossRef]

49. Brown, G.; Assaker, G.; Reis, A. Visiting Fortaleza: Motivation, satisfaction and revisit intentions of spectators at the Brazil 2014 FIFA World Cup. J. Sport Tour. 2018, 22, 1-19. [CrossRef]

50. Wen, J.; Huang, S. The effects of push and pull travel motivations, personal values, and destination familiarity on tourist loyalty: A study of Chinese cigar tourists to Cuba. Asia Pac. J. Tour. Res. 2019, 24, 805-821. [CrossRef]

51. Khan, M.J.; Chelliah, S.; Ahmed, S. Intention to visit India among potential travellers: Role of travel motivation, perceived travel risks, and travel constraints. Tour. Hosp. Res. 2019, 19, 351-367. [CrossRef]

52. Woodside, A.G.; Lysonski, S. A general model of traveler destination choice. J. Travel Res. 1989, $27,8-14$. [CrossRef]

53. Mannell, R.C.; Iso-Ahola, S.E. Psychological nature of leisure and tourism experience. Ann. Tour. Res. 1987, 14, 314-331. [CrossRef] 
54. Ross, E.L.D.; Iso-Ahola, S.E. Sightseeing tourists' motivation and satisfaction. Ann. Tour. Res. 1991, 18, 226-237. [CrossRef]

55. Jang, S.; Bai, B.; Hu, C.; Wu, C.M.E. Affect, travel motivation, and travel intention: A senior market. J. Hosp. Tour. Res. 2009, 33, 51-73. [CrossRef]

56. Lien, C.H.; Cao, Y.; Zhou, X. Service quality, satisfaction, stickiness, and usage intentions: An exploratory evaluation in the context of WeChat services. Comput. Hum. Behav. 2017, 68, 403-410. [CrossRef]

57. Martín-Consuegra, D.; Díaz, E.; Gómez, M.; Molina, A. Examining consumer luxury brand-related behavior intentions in a social media context: The moderating role of hedonic and utilitarian motivations. Physiol. Behav. 2019, 200, 104-110. [CrossRef]

58. Fishbein, M.; Ajzen, I. Belief, attitude, intention, and behavior: An introduction to theory and research. J. Bus. Ventur. 1977, 5, 177-189.

59. Davis, F.D. Perceived usefulness, perceived ease of use, and user acceptance of information technology. MIS Q. 1989, 13, 319-340. [CrossRef]

60. Jayawardhena, C. Personal values' influence on e-shopping attitude and behaviour. Internet Res. 2004, 14, 127-138. [CrossRef]

61. Shi, T.T.; Chen, S.T. Analysis of Service Content and User Needs for WeChat Official Accounts owned by Tourist Destinations-Using 5A Scenic Areas in Guangdong as An Example. Tour. Res. 2019, 11, $26-41$.

62. Verhagen, T.; Swen, E.; Feldberg, F.; Merikivi, J. Benefitting from virtual customer environments: An empirical study of customer engagement. Comput. Hum. Behav. 2015, 48, 340-357. [CrossRef]

63. Charfi, A.A. Immersion and perceived value: The strategic variables for commercial Websites. Int. J. Online Mark. 2014, 4, 17-35. [CrossRef]

64. Cui, X.; Lai, V.S.; Lowry, P.B. How do bidders' organism reactions mediate auction stimuli and bidder loyalty in online auctions? The case of Taobao in China. Inf. Manag. 2016, 53, 609-624. [CrossRef]

65. Leung, X.Y.; Bai, B. How motivation, opportunity, and ability impact travelers' social media involvement and revisit intention. J. Travel Tour. Mark. 2013, 30, 58-77. [CrossRef]

66. Chen, Y.C.; Shang, R.A.; Li, M.J. The effects of perceived relevance of travel blogs' content on the behavioral intention to visit a tourist destination. Comput. Hum. Behav. 2014, 30, 787-799. [CrossRef]

67. Xinhuanet. Overview of Fujian. Available online: http://www.travelfujian.com/findfj.php (accessed on 1 June 2020).

68. Fujian Provincial Bureau of Statistics. The Total Tourism Revenue of Fujian Province Exceeded 660 Billion Yuan. 2018. Available online: http://www.askci.com/news/chanye/20190307/1424291142842.shtml (accessed on 7 March 2019).

69. Chinadaily. Fujian Leads Nation in Ecological Preservation. Available online: http://fujian.chinadaily.com. cn/2019-06/04/c_385759.htm (accessed on 4 June 2019).

70. Guo, L.; Zhang, M.; Kang, K.; Hu, M. Transforming followers into fans: A study of Chinese users of the WeChat Official Account. Online Inf. Rev. 2017, 41, 1029-1045. [CrossRef]

71. Chen, X.; Ma, J.; Jin, J.; Fosh, P. Information privacy, gender differences, and intrinsic motivation in the workplace. Int. J. Inf. Manag. 2013, 33, 917-926. [CrossRef]

72. Shi, J.; Jiang, Y.; Hu, P.; Gong, Y.; Li, Y. A surveying study on social satisfaction to current doctor-patient relationship in China. J. Serv. Sci. Manag. 2015, 8, 695-702. [CrossRef]

73. CNNIC. The 44th China Internet Network Development Report. Available online: http://www.cac.gov.cn/ 2019-08/30/c_1124938750.htm (accessed on 30 August 2019).

74. Kline, R.B. Principles and Practice of Structural Equation Modeling; Guilford Press: New York, NY, USA, 1998.

75. Hair, J.F.; Black, W.C.; Babin, B.J.; Anderson, R.E.; Tatham, R. Multivariate Data Analysis; Pearson Education: Upper Saddle River, NJ, USA, 2006.

76. Fornell, C.; Larcker, D.F. Evaluating structural equation models with unobservable variables and measurement error. J. Mark. Res. 1981, 18, 39-50. [CrossRef]

77. Cheung, G.W. Introducing the latent congruence model for improving the assessment of similarity, agreement, and fit in organizational research. Organ. Res. Methods 2009, 12, 6-33. [CrossRef]

78. Lau, R.S.; Cheung, G.W. Estimating and comparing specific mediation effects in complex latent variable models. Organ. Res. Methods 2012, 15, 3-16. [CrossRef] 
79. Hur, K.; Kim, T.T.; Karatepe, O.M.; Lee, G. An exploration of the factors influencing social media continuance usage and information sharing intentions among Korean travellers. Tour. Manag. 2017, 63, 170-178. [CrossRef]

80. Chung, N.; Han, H.; Koo, C. Adoption of travel information in user-generated content on social media: The moderating effect of social presence. Behav. Inf. Technol. 2015, 34, 902-919. [CrossRef]

81. Lee, C.S.; Ma, L. News sharing in social media: The effect of gratifications and prior experience. Comput. Hum. Behav. 2012, 28, 331-339. [CrossRef]

82. Luo, M.M.; Chea, S.; Chen, J.S. Web-based information service adoption: A comparison of the motivational model and the uses and gratifications theory. Decis. Support Syst. 2011, 51, 21-30. [CrossRef]

83. Tsai, C.Y. An analysis of usage intentions for mobile travel guide systems. Afr. J. Bus. Manag. 2010, 4, 2962-2970.

84. Kim, D.Y.; Hwang, Y.H.; Fesenmaier, D.R. Modeling tourism advertising effectiveness. J. Travel Res. 2005, 44, 42-49. [CrossRef]

85. Lin, Y.S.; Huang, J.Y. Marketing of South Korean tourism using TV miniseries. Bus. Rev. 2006, 5, 61-65.

86. Chiu, C.C.; Yang, H.E. The Impact of Website Design Features on Behavioral Intentions. Int. J. Sci. Technol. Res. 2016, 9, 71-78.

87. Aluri, A.; Slevitch, L.; Larzelere, R. The influence of embedded social media channels on travelers' gratifications, satisfaction, and purchase intentions. Cornell Hosp. Q. 2016, 57, 250-267. [CrossRef]

88. Chan, C. When One App Rules Them All: The Case of WeChat and Mobile in China. Recuperado De. Available online: http://a16z.com/2015/08/06/wechat-china-mobile-first (accessed on 6 August 2015).

89. Karatsoli, M.; Nathanail, E. Examining gender differences of social media use for activity planning and travel choices. Eur. Transp. Res. Rev. 2020, 12, 1-9. [CrossRef]

90. Xu, F.; Nash, N.; Whitmarsh, L. Big data or small data? A methodological review of sustainable tourism. J. Sustain. Tour. 2020, 28, 144-163. [CrossRef]

91. Cintia Ganesha Putri, D.; Leu, J.S.; Seda, P. Design of an Unsupervised Machine Learning-Based Movie Recommender System. Symmetry 2020, 12, 185. [CrossRef]

92. Li, J.; Ren, J.L.; Liu, X.; Fan, J. Research on Continuance Use Intention of WeChat Public Platform. Inf. Sci. 2016, 10, 26-33.

93. Ducoffe, R.H. Advertising value and advertising on the web-Blog@ management. J. Advert. Res. 1996, 36, 21-32.

94. Bhattacherjee, A. Understanding information systems continuance: An expectation-confirmation model. MIS Q. 2001, 25, 351-370. [CrossRef]

95. Wang, Y.; Fesenmaier, D.R. Towards understanding members' general participation in and active contribution to an online travel community. Tour. Manag. 2004, 25, 709-722. [CrossRef]

96. Woodside, A.G.; Frey, L.L.; Daly, R.T. Linking sort/ice anlity, customer satisfaction, and behavioral intention. J. Health Care Mark. 1989, 9, 5-17.

(C) 2020 by the authors. Licensee MDPI, Basel, Switzerland. This article is an open access article distributed under the terms and conditions of the Creative Commons Attribution (CC BY) license (http://creativecommons.org/licenses/by/4.0/). 